\title{
Bacillus Species as Direct-Fed Microbial Antibiotic Alternatives for Monogastric Production
}

\author{
Shifa A. Bahaddad ${ }^{1}$ - Meshal H. K. Almalki ${ }^{1}$ Othman A. Alghamdi ${ }^{1}$ Sayed S. Sohrab ${ }^{2} \cdot$ Muhammad Yasir $^{2}$. \\ Esam I. Azhar ${ }^{2} \cdot$ Hichem Chouayekh ${ }^{1}$ (1)
}

Accepted: 9 January 2022 / Published online: 29 January 2022

(C) The Author(s), under exclusive licence to Springer Science+Business Media, LLC, part of Springer Nature 2022

\begin{abstract}
Antibiotic growth promoters have been utilized for long time at subtherapeutic levels as feed supplements in monogastric animal rations. Because of their side-effects such as antibiotic resistance, reduction of beneficial bacteria in the gut, and dysbiosis, it is necessary to look for non-therapeutic alternatives. Probiotics play an important role as the key substitutes to antibacterial agents due to their many beneficial effects on the monogastric animal host. For instance, enhancement of the gut microbiota balance can contribute to improvement of feed utilization efficiency, nutrients absorption, growth rate, and economic profitability of livestock. Probiotics are defined as "live microorganisms that, when administered in adequate amounts, confer a health benefit on the host." They are available in diverse forms for use as feed supplements. Their utilization as feed additives assists in good digestion of feed ingredients and hence, making the nutrients available for promoting growth. Immunity can also be enhanced by supplementing probiotics to monogastrics diets. Moreover, probiotics can help in improving major meat quality traits and countering a variety of monogastric animals infectious diseases. A proper selection of the probiotic strains is required in order to confer optimal beneficial effects. The present review focuses on the general functional, safety, and technological screening criteria for selection of ideal Bacillus probiotics as feed supplements as well as their mechanism of action and beneficial effects on monogastric animals for improving production performance and health status.
\end{abstract}

Keywords Probiotic $\cdot$ Bacillus $\cdot$ Antibiotic alternative $\cdot$ Feed additive $\cdot$ Mode of action $\cdot$ Gut microbiota

\section{Introduction}

Livestock production is hugely contributing to the economic growth of most countries. It has increased considerably during last decades so as to provide sufficient food for the growing world population that is expected to exceed 9 billion by 2050 [1]. The availability of enough protein sources through terrestrial and aquatic animals production is vital for meeting the growing demand for protein, an essential constituent of a balanced nutrition [2]. The extensive use of antibacterial agents at sub-therapeutical levels as growth-promoting

Hichem Chouayekh

hschouayekh@uj.edu.sa

1 Department of Biological Sciences, College of Science, University of Jeddah, Jeddah, Kingdom of Saudi Arabia

2 Special Infectious Agents Unit, King Fahd Medical Research Center, King Abdulaziz University, Jeddah, Kingdom of Saudi Arabia compounds has long been practiced in livestock production to enhance feed conversion efficacy and growth performance in commercial animal production systems [3]. However, increased antibiotic supplementation to animal feed has led to antibiotic-resistant pathogenic bacteria that menace human health because of the risk of transferring antibiotic resistance genes to the human microbiota through consumption of animal-derived products $[4,5]$. From the economic point of view, emergence of antibiotic resistances has led to failure of antibiotic treatments, losses in livestock production, and increased risk of zoonotic infections [6]. In view of the increasing regulatory agencies pressure and consumer demand for safe food, the use of antibiotic growth promoters (AGPs) as feed supplements has been banned in majority of countries with Sweeden being the first one to ban AGPs in 1986 [7]. Thus, to keep current production performance indicators in animal industry, several possible alternatives including probiotics, feed enzymes, prebiotic oligosaccharides, synbiotics, essential oils, and immunostimulants have 
received an overwhelming interest during the few last decades [8]. Among those substitutes, probiotics or direct-fed microbials (DFM), have generated major interest in livestock production considered as one of the fastest-growing sectors in agriculture [9]. They were defined as "non-pathogenic live microbial cells feed supplements which exert beneficial effects on both health and physiology of the target animal host, in addition to the improvement of intestinal microbiota balance, stimulation of the immune system, and overall progression in animal growth and performance"[10].

Bacillus species have a global reputation of being Generally Recognized As Safe (GRAS) microorganisms. However, some members of the species B. cereus, B. alvei, $B$. brevis, $B$. circulans, $B$. coagulans, $B$. infantis, $B$. idriensis, $B$. laterosporus, B. licheniformis, B. macerans, B. pumilus, B. sphaericus, B. subtilis, and B. thuringiensis can be pathogenic and have been linked to discomforts and diseases [11]. Bacillus species have the capacity to form spores withstanding harsh conditions and recently shown tremendous promise to be used as probiotics [12,13]. Also, they are able to produce antagonistic substances against a wide range of bacterial pathogens, provide extracellular digestive enzymes (phytase, $\beta$-glucanase, xylanase, amylase, protease, $\beta$-mannanase) that enhance feed digestibility and nutrients absorption, and regulate the animal host immunity $[14,15]$. Additionally, Bacillus DFM have proved ability to enhance both cellular and humoral immune responses through rising the number of solitary lymphoid follicles in the intestinal mucosa, controlling the development of the gut-associated lymphoid tissue (GALT), stimulating antibody responses after vaccination, and enhancing macrophage function [16]. The principal effects of probiotic additives include a remarkable resistance to pathogenic bacteria colonization and improved host mucosa immunity which can be manifested by a reduced pathogen load, an improved health status of the animal host, and a reduced risk of contamination of animal products with harmful foodborne pathogens [17]. Also, Bacillus strains are forming endospores that can resist harsh intestinal conditions, survive extreme temperatures during the feed pelleting procedure, and tolerate extreme $\mathrm{pH}$ conditions, dehydratation, high pressures, and caustics [18]. All these properties as well as their long shelf life render Bacillus DFM strains and their endospores an ideal feed supplement [19].

This review reports the level of general development in the impressive Bacillus probiotic scientific research for application in monogastrics (terrestrial and aquatic animals like poultry, pigs, and fish), with a critical assessment of principal general functional, safety, and technological screening criteria for selection of ideal Bacillus probiotics and their mode of action and beneficial effects on the monogastric animals. Furthermore, up-to-date Bacillus spore innovation technology entailing nanobiotechnology, adsorption, and surface display of proteins for improving the feed utilization efficiency is discussed.

\section{Sources, Isolation, Identification Technique, and Probiotic Characterization of Strains Belonging to the Genus Bacillus}

To date, many Gram-positive bacterial species including lactic acid bacteria, Bacillus, and Bifidobacterium have been reported as health-promoting probiotics in livestock production [20]. However, among these, strains selected from the genus Bacillus have more evident intrinsic advantages when compared to the other non-sporulating ones [21]. Indeed, they can germinate, multiply rapidly, and endure a multi-tude

Table 1 Sources of Bacillus probiotic strains and identification technique

\begin{tabular}{|c|c|c|c|c|}
\hline Source & Bacillus strain & Identification technique & Animal model & References \\
\hline Soil & B. subtilis HB2 & $\begin{array}{l}\text { 16S ribosomal RNA gene amplification and sequence } \\
\text { analysis }\end{array}$ & Poultry & [24] \\
\hline Soil & $\begin{array}{l}\text { B. amyloliquefaciens DSM } \\
25,840 \text { or B. subtilis } \\
\text { DSM32324 }\end{array}$ & $\begin{array}{l}\text { 16S ribosomal RNA gene amplification and sequence } \\
\text { analysis }\end{array}$ & Piglets & [25] \\
\hline Fermented pickles & B. subtilis L10 and G1 & $\begin{array}{l}\text { 16S ribosomal RNA gene amplification and sequence } \\
\text { analysis }\end{array}$ & Shrimp & [26] \\
\hline Weaned pig & B. subtilis $\mathrm{KN}-42$ & $\begin{array}{l}\text { 16S ribosomal RNA gene amplification and sequence } \\
\text { analysis }\end{array}$ & Pig & [27] \\
\hline Gut of fish & B. subtilis ANSB060 & Phenotypic characters and 16S rRNA gene sequencing & Broiler & [23] \\
\hline $\begin{array}{l}\text { Digestive tract of } \\
\text { freshwater fish }\end{array}$ & $\begin{array}{l}\text { B. subtilis } \mathrm{KX} 756706 \\
\text { B. cereus } \mathrm{KX} 756707 \\
\text { B. amyloliquefaciens } \mathrm{KX} 775224\end{array}$ & $\begin{array}{l}\text { 16S ribosomal RNA gene amplification and sequence } \\
\text { analysis }\end{array}$ & Fish & [28] \\
\hline $\begin{array}{r}\text { Gastrointestinal } \\
\text { tract of young } \\
\text { broiler chicks }\end{array}$ & B. subtilis PRO & $\begin{array}{l}\text { 16S ribosomal RNA gene amplification and sequence } \\
\text { analysis }\end{array}$ & Poultry & [29] \\
\hline
\end{tabular}


of severe environmental conditions, providing a wide range of health benefits on the host. For instance, application of Bacillus probiotics can enhance growth as well as immune function of animal host and help in maintaining a balanced gut microbiota [22]. Potential Bacillus probiotics used for monogastric animals are typically isolated from the gastrointestinal tract (GIT) of those animals or from other sources such as soil, aquatic environment, plants, and marine algae [23]. The majority of characterized Bacillus probiotic strains are members of the subtilis species or closely related ones [14]. Table 1 provides examples of sources of Bacillus strains used in different monogastric animal models along with their principal identification technique.

\section{Functional Criteria for Desirable Bacillus Probiotic Properties}

Bacillus species, which enjoy GRAS status from the US Food and Drug Administration (FDA) and are included in the Qualified Presumption of Safety (QPS) list of the
European Food Safety Authority (EFSA), have recently shown tremendous promise as probiotics [23]. Functional, safety, and technological characteristics must be considered in the selection process of probiotic Bacillus destined to monogastric animals as illustrated in Fig. 1. The probiotic strain must fulfill several functional aspects. For instance, it is preferred that probiotic candidate is a GRAS normal resident of the targeted monogastric gut, and capable of persisting in the GIT of that animal [30]. Also, survival to the digestive stresses, exhibition of antagonistic and antimutagenic properties, efficiency in immunomodulation and competitive exclusion (CE) are prerequisite [30].

To provide the expected positive effects on the monogastric animal host, probiotic Bacillus must have the ability to survive, colonize, and persist, at least transitorily, in the host GIT [31]. Several Bacillus strains have been screened using in vitro as well as in vivo models for their potential probiotic functional properties [32]. Bacillus spores can withstand harsh environmental stresses like the extreme acidic $\mathrm{pH}$ of the stomach, and tolerate bile salts along with other adverse conditions within the animal GIT [32]. Besides, bacilli are

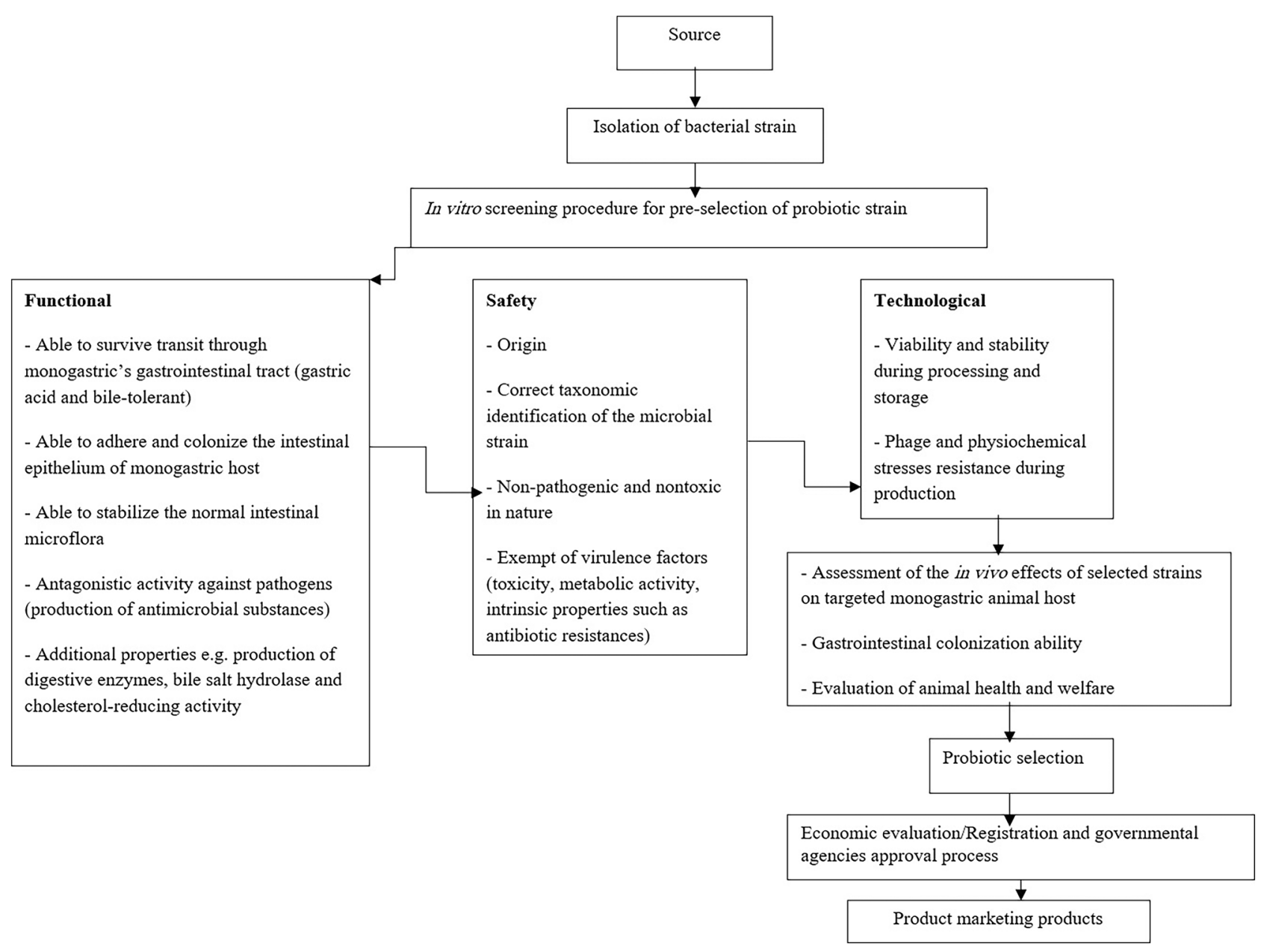

Fig. 1 Diagram providing the different criteria required for the selection of Bacillus strains as promising probiotics 
more stable during handling and storage of food and pharmaceutical products, an advantageous property that make them pretty ingredients in formulating preparations with health promoting potential [32].

\section{Bacillus Probiotics Induce Gut Microbiota Modulation}

Ability to adhere to the intestinal mucosa is among the principal selection criteria for novel and existing probiotic strains. The property of Bacillus spore adhesion is essential for colonization, leading to the interaction between the probiotic and targeted host that is also linked to the ability of the strain to modulate the immune function [8]. Supplementation of Bacillus as DFM can positively influence host gut microbiota composition by reducing the competition for nutrients which contributes to increasing beneficial bacteria and improving GIT health [8]. Also, probiotics that belong to the genus Bacillus as well as the Lactobacillus and Saccharomyces genera, are among the most common supplements with proven ability to lower Firmicutes/Bacteroidetes ratio and prevent obesity [33]. Wang et al. (2017) suggested that Bacillus amyloliquefaciens SC06 can help to prevent obesity and its related liver damage by modifying the antioxidant capacity of swine intestinal epithelial cells and host gut microbiota [34]. In chickens, microbial colonization of the GIT starts at hatch and quickly increases [35]. Within $24 \mathrm{~h}$, the microbial count in the proximal and distal intestine can attain $10^{8}$ and $10^{10}$ cells/g, respectively [35]. Early supplementation with Bacillus spp. as a DFM is vital to maintain a durable presence within the animal's gut community [9]. Previous studies have proved that application of Bacillus spp. as a DFM improves in general the intestinal health and growth performance in chickens, but once more, the exact involved mechanisms are still unknown [9]. The literature reports that Bacillus spores are not reactive before ingestion [36]. But, they have the ability to quickly germinate once becoming within the chickens' GIT environment. The vegetative cells can develop from spores within $20 \mathrm{~h}$ after oral administration and could be detected all along the small intestine segments, ceca, and colon [37]. Bacillus DFM could influence the distribution and colonization of the intrinsic microbiota along the GIT and stimulate the growth and proliferation of other beneficial health-promoting bacteria [9]. One presented theory speculates that the growth-promoting effects of DFM in poultry production are principally linked to reduced numbering and diversity of the innate microbiota, which allows for increased nutrients absorption by the host intestinal epithelial cells and reduced detrimental effects of the microbial-derived metabolites [3].

\section{Bacillus Probiotics Induce Gut Morphological and Immunological Changes}

The probiotic-derived metabolites, DNA, and components of cell wall can contribute to the stimulation of the host immune system. This can be achieved throughout interaction with epithelial cells and effectors/regulators of the innate and adaptive immune responses like monocytes, macrophages, and dendritic cells. The immune response mechanisms might be local and restricted to the stimulation of host gut immunity such as stimulation of the production of secretory $\operatorname{IgA}$ (sIgA) or systemic immunity [38]. The bacterial adherence to intestinal enterocytes is not only helpful for gut colonization, but can as well boost the gut-specific lymphoid tissue immune cells [39]. Previous reports strongly suggest that spores of $B$. subtilis are able to translocate through microfold cells that are located in the epithelium covering mucosaassociated lymphoid tissues like the Peyer's patches (PPs) of the small intestine prior to be transported to efferent lymph nodes [40]. These PPs are rich in antigen-presenting cells including dendritic cells and macrophages, that are widely contributing to antigens processing and presentation to $\mathrm{B}$ cells allowing the production of sIgA [41]. Stimulation of sIgA production as the principal antibody class in mucosal secretions is crucial for neutralization of pathogenic microorganisms [41].

On the other hand, various studies have revealed that spores of Bacillus can similarly stimulate phagocytosis mediated by macrophages that are a cornerstone of the innate immune system [42]. It is well documented that the immune function modulation or the host immune systems stimulation are vital characteristics of possible probiotic candidates and are linked to their antagonism potential [32]. These antagonistic effects of probiotics are indispensable to stop or lower pathogenic infection [32]. Bacillus DFM can interact directly with the host to generate a beneficial immune response against harmful pathogens at the intestinal epithelium of chickens [9]. Good gut health plays a key role in enhancing effectiveness of poultry production as it directly correlates with improved growth and production performances [9]. Many factors linked to disease and stress are able to cause disruption of intestinal epithelial integrity that consequently reduces nutrients absorption efficiency and increases the risk of pathogenic invasion and inflammatory diseases development. Thus, a notable reduction in growth performance is expected [43]. Animal's gut barrier function should be preserved in order to protect the host from dangerous biological or chemical invading agents [44]. This can be achieved by two major mechanisms including the epithelial goblet cells-mediated secretion of the protective mucus blanket [45]. The mucus is composed mainly of 
mucin glycoproteins responsible for the viscous properties, water, salts, lipids, and several proteins exhibiting protective functions [46]. DFM, such as those belonging to the genus Bacillus, can induce the expression of $M U C 2$ gene responsible for mucin production, to neutralize the inflammation triggered by pathogenic germs [46]. When inducing an inflammatory response in chickens by intraperitoneal injection of lipopolysaccharide (LPS) from Escherichia coli [47], the group which was fed with the probiotic B. subtilis 1781 strain showed significant increase in the ileum MUC2 expression levels [48]. This up-regulation corroborated with remarkable reduce in inflammation signs as observed by decreased $\alpha-1$-acid glycoprotein ( $\alpha-1$-AGP) expression, that is frequently associated with severe colitis [48]. In addition, the up-regulation of $M U C 2$ expression was found to be also probably induced in response to the LPS circulating in chicken blood, and not exclusively just as a result of the direct contact with intestinal epithelium [48].

\section{Metabolic Features of the Genus Bacillus}

The antagonistic activities are of major importance in the procedure of potential probiotics screening [49]. These activities are tightly associated with the ability to release antimicrobial agents supporting $\mathrm{CE}$ of pathogens [20]. The term "CE" is defined as the aptitude of desirable probiotic bacteria to enter in competition with undesirable gastrointestinal pathogens for adhesion to intestinal surfaces [50]. For instance, among the desirable probiotic properties of B. subtilis KMP-N004 is the inhibition of pathogens adhesion to porcine enterocytes [51]. Bacillus strains are known as potent producers of a wide variety of antimicrobial substances among them, lipopeptides like surfactin, iturin, and fengycin; bacteriocins; and bacteriocin-like inhibitory substances [52, 53]. In general, these antimicrobial compounds are principally efficient against Gram-positive bacterial pathogens, but few of them also show antagonistic potential toward some pathogenic Gram-negative bacteria and fungi [54].

On another hand, it is well documented that the recent tremendous potential of Bacillus species as probiotics is tightly linked to their inherent capacity to produce spores from initial vegetative cells [55]. They possess several advantages over other non-spore formers such as members of the genus Lactobacillus [55]. Indeed, Bacillus spores are naturally stable and able to resist harsh environmental stressful conditions and transitions during storage and handling without any loss in their vital potential [56]. This includes high temperatures of the feed pelletization procedure (around $80{ }^{\circ} \mathrm{C}$ ), extreme $\mathrm{pH}$, dehydration, and high pressures [57]. In addition, vitality of Bacillus spores is often not compromised by bile and acidic $\mathrm{pH}$ values encountered in the GIT of monogastrics compared to vegetative cells [58]. Several reports have claimed that ingested Bacillus spores are able to germinate in the intestinal compartment and may exert their expected beneficial effects on the monogastric animal host through the production of wide range of bioactive metabolites, including the release of antimicrobial compounds supporting CE of pathogenic bacteria [23]. The adhesion to intestinal epithelial cells of the host is among the key advantageous properties examined during the procedure of probiotic candidates screening [59]. Generally, the spores of Bacillus are characterized by a higher hydrophobicity and superior adhesion ability when compared to the vegetative cells living form [60]. A correlation between surface hydrophobicity and good adhesion capacity of Bacillus isolates has also been reported [61]. The superior hydrophobicity of spores is most likely attributable to the existence of surfaceassociated proteins that probably play key role in the adhesion property of probiotic strains to the GIT [23].

In addition to spores formation ability and production of antimicrobial compounds, several Bacillus probiotic strains are able to liberate directly in the lumen of the host digestive tract, a variety of extracellular digestive enzymes including phytase, xylanase, $\beta$-glucanase, $\beta$-mannanase, amylase, protease, and lipase [56]. These enzymes can improve feed conversion ratio (FCR) by reduction of anti-nutritional factors in plant-derived feedstuffs like non-starch polysaccharides (NSP), enhancement of feed ingredients digestibility, and absorption of nutrients [62]. While the principal interest of using these enzymes is the improvement of digestion, some of them can also be implicated in the lysing of the cell wall components of pathogenic microbes which in turn causes the global resistance of the animal host against these pathogens [63]. It is well known that the abundance of NSP in diets increases the host intestinal viscosity and affects negatively the digestibility, the nutrients absorption, and growth performance [64]. Neutralizing the adverse effects generated by NSP can be achieved by supplementation of animal diet with the corresponding microbial enzymes or a multi-enzymes producing DFM [65].

\section{Safety Criteria for Selection of Promising Bacillus Probiotic Strains}

Safety aspects that probiotic candidates must meet include specifications like origin (healthy relevant animals' GIT) as well as lack of any traits of pathogenicity, nondigestive discomforts, and heritable antibiotic resistance genes [58]. The identity of microorganisms is usually ascertained primarily before evaluating them for their probiotic attributes [66]. Microbes are subjected to a battery of morphological, biochemical, and molecular tests to assign them to the corresponding genus and species [67]. In general, the 16S rDNA 
gene sequencing proved to be insufficient to easily distinguish between Bacillus species that are closely related [68]. Analysis of additional molecular markers like $\mathrm{gyr} A$ or $\mathrm{gyr} B$ genes can be helpful [68]. Closely related bacterial isolates from the same species are further differentiated to sub species and strain level using newer and established techniques, such as DNA fingerprinting, sequencing of selected genes, oligonucleotide probes, pulse-field gel electrophoresis etc. [69]. Other molecular techniques, including denaturing/ temperature gradient gel electrophoresis and fluorescence in situ hybridization, are utilized to identify and characterize probiotic strains [70]. Recent development in whole genome sequencing technologies allows precise taxonomic identification of potential Bacillus probiotic candidates and especially provides information about the presence of antibiotic resistance genes and virulence factors as well as the possible pathogenicity toward monogastric host [71].

To confirm that probiotic products are safe to consume and safeguarding health, regulatory quality control, and strict rules are required [71]. Among these, the disadvantage of toxin production that can be detected in some Bacillus strains is a main safety problem for their administration to animal hosts [32]. B. cereus is one of the more important causes of food poisoning. It produces one emetic toxin and different enterotoxins [72]. The diarrheal syndrome is caused by the production of three different heat-labile enterotoxins all through vegetative growth of $B$. cereus in the small intestine [72], whereas the emetic-type illness is caused by a heat-stable emetic toxin called cereulide, produced under various conditions during the growth of $B$. cereus in the food itself [73]. B. cereus also has the ability to release various other kinds of toxins such as enterotoxin T, enterotoxin FM, and cytotoxin $\mathrm{K}$ [72]. In addition to the well-documented previously cited toxins, many other virulence factors including hemolysins and cerolysins are also involved in the toxic activity of enterotoxins from B. cereus strains [74]. Besides the well-known pathogenic $B$. cereus, sporadically other species from the Bacillus genus showed the ability to release metabolites exhibiting significant toxicity towards mammalian cells, such as the heat-stable toxin amylosin, that can be liberated by bacilli associated with food poisoning like $B$. subtilis, B. amyloliquefaciens, and B. mojavensis [75]. During the screening strategy, strains showing cytotoxicity are not endorsed for use as probiotic candidates [76].

Another threat that should be seriously considered is the capacity of some Bacillus isolates to hold transmissible antibiotic resistance determinants, especially resistance genes that are carried by plasmids as well as mobile genetic elements such as transposons and insertion sequences [77]. Horizontal gene transfer within the host GIT might occur between probiotic and opportunistic or pathogenic bacterial strains. For instance, aminoglycosides, macrolides, $\beta$-lactams, and chloramphenicol resistance genes have been detected in B. clausii DSM8716 probiotic strain [78, 79]. The tetracycline resistance gene tet $M$ that belongs to the $B$. cereus group, was found to be carried by Tn916-like transposon that could be transmitted to B. subtilis, Staphylococcus aureus, and enterococci [23]. Besides, the tet $K$ gene conferring resistance to chlortetracycline in $B$. subtilis was carried by a plasmid which could be received by $E$. coli via conjugative transfer [80]. Transfer of genes conferring resistance to antibiotics between bacteria contributes to the development of acquired antibiotic resistances which result in the failure of treating certain infections and economic losses in animal production systems [81]. For this reason, the EFSA has recommended that the Bacillus-based products intended for use as feed supplements should be checked for sensitivity to antibiotics commonly used in human and veterinary medicine to avoid any resistance spreading [82]. The antimicrobial resistances that should be checked in Bacillus species include for example, vancomycin, tetracycline, chloramphenicol, gentamicin, kanamycin, streptomycin, erythromycin, and clindamycin [82].

\section{Technological Requirements to Assess Probiotic Strain Viability and Stability}

In addition to the functional and safety aspects, probiotic bacteria must also meet the technological criteria linked to the production and processing of animal feed. Moreover, resistance to in vitro as well as in vivo conditions after administration of the probiotic is important [83]. For example, the probiotic microorganism should not be killed by the host's defense mechanisms and able to withstand the specific conditions occurring during the transit in the monogastric host [83]. A major quality criterion that must be met in the manufacture, regulation, and marketing of DFM is the precise definition of the number of viable cells in the feed additive product in accordance with the label [84]. A variety of methods can be used to determine the bacterial concentration in commercial preparations. These include traditional plating assays, optical density measurements (turbidity), direct counting methods like flow cytometry, quantitative polymerase chain reaction, cell mass determination, and measurements of cellular activity [85]. Depending on the precise product matrix, one assay technique can be chosen for better precision and reproducibility [86]. On the other hand, economical evaluation of probiotic preparation and endorsement by an official certification service must be done prior to large scale production and commercialization. A 
diagram that summarizes the diverse criteria that Bacillus probiotic strains must meet in order to be considered beneficial feed supplements is shown in Fig. 1.

\section{Modes of Action and Beneficial Effects of Bacillus for Monogastric Animals}

Probiotic bacteria from the genus Bacillus are expected to balance the gut microbiota generating beneficial activities to the animal host. We classified the modes of action of these DFM in the following:

\section{Competition for Adhesion to Epithelial Layer}

The mechanism by which probiotic bacteria compete for intestinal adhesion sites is designated as "CE." Among the main properties required for selection of adequate Bacillus DFM candidates are the strain ability to adhere to the epithelial surface, colonize the monogastric host gut, and subsequently form a barrier on the intestinal surface to prevent the adhesion of pathogenic microorganisms [87]. A recent study has demonstrated that $B$. subtilis $\mathrm{C}-3102$ supplementation over a period of 3 weeks accelerates exclusion of the pathogen Salmonella enterica from the cecum, liver, and spleen of the chickens in a dose-dependent manner [88]. Many Bacillus probiotic candidates have shown excellent in vitro adhesion efficacy. For instance, the B. amyloliquefaciens US573 was found to exhibit good adhesion efficacy to chicken enterocytes collected from the duodenum, jejunum, and ileum [89]. In addition, Gu et al. (2015) have observed that the B. coagulans CGMCC 9951 strain exhibited stronger adhesion to pig intestinal mucus than that of B. subtilis JT143 and L. acidophilus LY24 strains isolated from two commercial probiotic preparations [90]. High in vitro adhesion to mucus was also shown for the Bacillus amyloliquefaciens COFCAU_P1 strain isolated from the digestive tract of a freshwater teleost rohu (Labeo rohita) [91]. Mucus-binding and surface-associated proteins are among the principal determinants involved in the adhesion as revealed by genome sequencing of many Bacillus probiotic strains [90].

\section{Production of Inhibitory Substances}

Many Bacillus species are renowned producers of antimicrobial peptides, especially bacteriocins which are small ribosomally synthesized peptides released for bacterial antagonism in a given natural ecosystem [92]. These Bacillus-derived bacteriocins affect principally Gram-positive bacteria by binding onto their outer membranes for disruption of the membrane biosynthesis [93]. Bacteriocins can serve as colonizing peptides by facilitating the installation of probiotic strain into an already occupied niche on the intestinal epithelium. The competitive advantage confer to the probiotic Bacillus the capacity to invade host intestine surfaces [94]. Generally, bacteriocins produced by strains that are members of the genus Bacillus have the reputation to exhibit a wide antibacterial spectrum and to be active under extreme temperature and $\mathrm{pH}$ conditions [95]. For instance, B. amyloliquefaciens ZJHD3-06 strain isolated from the marine fish Epinephelus areolatus produces a novel bacteriocin namely "CAMT2" that has antagonistic activity against Listeria monocytogenes, Staphylococcus aureus, Escherichia coli, and Vibrio parahaemolyticus [96].

\section{Immune System Modulation}

Modulation of immune system is one of the most common benefits linked to dietary probiotic inclusion. The observed positive effects are depending on the monogastric animal, host immune system, probiotic strains used, and conditions of application [97]. For example, improvement in immune function reflected by serum $\operatorname{IgA}$ and $\operatorname{IgM}$ increases was noted in chickens fed with diets containing a mixture of $B$. subtilis BYS2 and BG5 [98]. Similarly, administration of $B$. subtilis promoted the increase in IgA concentrations in pigs [99]. Reduce or prevention of intestinal inflammatory reactions has been also observed in poultry following the administration of $B$. subtilis-based probiotics [100]. Regarding fish species, increase in lysozyme activity is among the noted beneficial effects of probiotic supplementation on immune system modulation. Lysozyme is an important defense protein (non-specific immunity). It has the ability to lyse the cell walls of Gram-positive bacteria and plays a key role in combating infection in fish. Many studies have shown that inclusion of different Bacillus subtilis strains in diets of various fish species increases mucus lysozyme activity. For instance, hybrid grouper fed with B. subtilis 6-3-1 strain exhibited significantly higher lysozyme activity level than fish fed with a control diet without probiotic supplementation [101].

\section{Production of Extracellular Hydrolytic Enzymes}

Currently, members of the spore-forming Bacillus genus are considered among the main sources of DFM destined for monogastric animals [102]. They have the ability to produce a wide range of extracellular enzymes that actively contribute to enhancement of digestion (carbohydrates hydrolases and proteolytic enzymes) and nutrients absorption [103]. A previous study reported that the selection of Bacillus DFM 
was depending on in vitro enzyme secretion profiles, which associated with reduce in supernatant viscosity and proliferation of Clostridium perfringens [62]. It was suggested that the extracellular enzymes which are secreted by the DFM could reduce the quantity of available nutrients that are required for growth of $C$. perfringens, stimulating the rate of transit of the digesta through the GIT and improving the intestinal microbial environment [104]. Cereal grains are among the regularly used ingredients in livestock animal feed. They are rich in anti-nutrional factors including NSP, resistant starch, and non-digestible proteins that are weakly digested by monogastrics. Additionally, the NSP can also exert anti-nutritive effects by chelating vital minerals like calcium, iron, and magnesium, reducing nutrients absorption as a result of increased ileal viscosity, and altering the host gut microbiota. Digestive enzymes such as xylanases, amylases, and proteases are regularly supplemented to animal feed to improve growth performance by enhancement of digestibility and alleviation of the anti-nutritive effects of poorly digested feed ingredients [105]. Additionally, the hydrolysis products of animal feedstuffs generated by exogenous enzymes used as feed supplements can contain substances like oligosaccharides that may promote the growth or metabolic activities of beneficial bacteria. Altogether, these observations suggest that the administration of particular enzyme blends can confer an additional advantage when combined with suitable DFM. Table 2 shows the main involved enzymes and their functions.

\section{Application of Probiotics in Livestock}

\section{In Poultry}

Bacillus probiotics are commonly utilized in the poultry sector. They can improve the growth and production efficiency of poultry birds, protect against pathogenic microbes, enhance the immune system responses, strengthen bones, and assist in fighting off parasite infections. Infection of chickens with some pathogenic bacteria including Salmonella spp., Clostridium perfringens and Campylobacter jejuni increases the risk of contamination at the different stages along the food chain resulting in a dangerous condition simultaneously for poultry and human. Therefore, probiotics can act as a natural alternative against of Campylobacter, Salmonella, and Escherichia coli in the preharvest stages [58]. For instance, the number of Enterobacteriaceae in the excreta decreased following B. subtilis C-3102 strain administration [112]. Feeding of broilers with this B. subtilis strain also causes a decrease in shedding of Campylobacter [113]. As well, dietary supplementation with either B. subtilis DSM17299 or $B$. cereus var. leads to significantly reduced Salmonella colonization [23]. Furthermore, B. subtilis PB6 addition to broilers causes a decreased number of $C$. perfringens in the intestine [114]. In addition to preventing gut colonization by the pathogen, feeding the poultry with Bacillus probiotic can enhance the FCR and improve weight gain. Other benefits for Bacillus as probiotic include the effects on broilers intestine histology and morphology, as the increase in the villus height as well as the villus height to crypt dept ratio. These effects, contribute to improving digestibility and increasing intestinal nutrients absorption capacity [115]. Broilers fed diets supplemented with Bacillus enzyme-producing probiotics showed decreased digesta viscosity that is caused by soluble NSP, which are known by their negative impact on availability and absorption of nutrients [116]. Besides enhancing the growth performances and promoting health of poultry, feed supplementation with Bacillus could also improve the meat quality (increase in meat lightness, redness and yellowness) [117] and eggs (increase in eggshell strength and thickness, yolk color score, Haugh unit, and decrease in cholesterol content of yolk) [118]. Bacillus can limit influence from toxin

Table 2 Main enzymes secreted by Bacillus strains and their functions in monogastric animals

\begin{tabular}{|c|c|c|c|c|}
\hline Enzyme & Producer strain & Substrate & Function & Reference \\
\hline Protease & Bacillus cereus AT & Proteins & Contributes to proteins digestion and improves FCR and weight gain & [106] \\
\hline Lipase & Bacillus methylotrophicus PS3 & Lipids & Digests lipids & [107] \\
\hline Cellulase & Bacillus subtilis BY-3 & Cellulose & Hydrolyzes cellulose, and enhances fiber degradation & {$[108]$} \\
\hline Xylanase & Bacillus subtilis $\mathrm{E} 44$ & Xylans & $\begin{array}{l}\text { Contributes to degradation of NSP as well as release of nutrients and } \\
\text { decreases intestinal chyme viscosity increasing animal production } \\
\text { efficiency }\end{array}$ & {$[106]$} \\
\hline Phytase & Bacillus subtilis US417 & Phytic acid & $\begin{array}{l}\text { Releases phosphorus }(\mathrm{P}) \text { from phytates contributing to better } \\
\text { bioavailability of } \mathrm{P} \text { and vital minerals and enhancement of growth } \\
\text { performance and health of animals along with environment protection }\end{array}$ & [109] \\
\hline Keratinase & Bacillus subtilis $\mathrm{S} 14$ & Keratin & Degrades keratin and improve digestion & {$[110]$} \\
\hline Mannanase & Bacillus amyloliquefaciens 10A1 & Mannans & $\begin{array}{l}\text { Contributes to degradation of NSP and decreases intestinal chyme } \\
\text { viscosity increasing animal production performance }\end{array}$ & [111] \\
\hline
\end{tabular}


in contaminated broilers feed and decrease emission of $\mathrm{NH}_{3}$ from poultry manure [23]. The increase in gut permeability caused by several enteric pathogens such as Salmonella spp results damage in the intestinal tight junction that referred as "leaky gut"' [119]. With inflammation, the leakage of serum fluorescein isothiocyanate dextran (FITC-d) increases which is judged as indicator to estimate enteric inflammation produced with gut permeability in broiler chickens [120]. During therapeutic study, the observed significant decrease $(p<0.05)$ of serum FITC-d level by DFM administration as compared to the untreated control group resulted in the reduction of negative effects of S. Enteritidis by increasing the tight junction proteins organization [121]. The vital role of antioxidant enzymes like super oxide dismutase (SOD) includes the degradation of reactive oxygen species (ROS) such as hydrogen peroxide and superoxide anions that are produced during the inflammatory process [122]. A significant $(p<0.05)$ increase of SOD activity was observed in the control group of the prophylactic and therapeutic study, when compared to the group fed with the DFM [121]. The increase in SOD activity in the control group could be linked to the reaction to increased oxidative stress attributable to severe intestinal damage caused by S. Enteritidis [121]. Also, the large increase in the amount of $\operatorname{IgA}(p<0.05)$ observed in both in vivo studies may be related with disruption of the intestinal epithelium, as intestinal IgA secretion acts as the first line of defense in protecting the intestinal epithelium from enteric toxins and pathogenic microorganisms, counteracting inflammatory processes and boosting the mechanism of non-specific defense [123]. On the other hand, as a consequence of DFM administration, the decrease in SOD activity as well as IgA level may be attributed to its anti-inflammatory and immune modulating properties to reduce the harmful effects of S. Enteritidis. This can minimize the intestinal morphological and immunological changes by cytoprotective proteins and modulation/regulation of cytokines expression. In addition, with implied health benefits for birds, the DFM was able to sustain bacterial species in the intestine while reducing potentially harmful populations. Hernandez-Patlan et al. (2019) showed that the addition of B. subtilis DSM 32,315 in broilers feed may stabilize the microbiome and prevent opportunistic pathogens like Campylobacter jejuni, E. coli, and various Salmonella spp. from other intestinal disorders [104]. The possible impacts of feeding with B. subtilis DSM32315 strain on physiological improvements and GIT function and immune system should be investigated to explain other potential actions of the probiotic that may have involvement in promoting health and increasing growth performance of poultry [104].

\section{In Pigs}

Similar to poultry, newborn pigs possess a sterile gut and gradually develop their typical microbiota through contact with their mother and the surrounding environment. The cycles after birth and post-weaning are the most susceptible times in the pig's life in which the removal of in-feed antimicrobial agents could have an effect on mortality [124]. Pigs are particularly sensitive to gut invasion by bacterial pathogens responsible for growth decrease and diarrhea during those cycles [125]. Furthermore, weaning exposes the piglets to a biological stress that can lead to dysfunctions of the intestinal and immune systems and can lead to decreased feed intake and growth along with altered pig health, particularly in the first week after weaning [126]. It has been claimed that during the first week after weaning, the microbiota in the pig gut fluctuates, and a duration of 2-3 weeks post-weaning is needed to stabilize gut microbes and completely improve their fermentation ability [127]. During these life stages, the piglet must be exposed to a shielding gut microbiota that would defend towards environmentally acquired pathogenic germs by both direct and indirect means (stimulation of host immune system), with the additional benefit of increasing the digestibility and absorption of nutrients [128]. Probiotic administration has been reported to influence in a positive way the feed intake and average live weight with greater neonatal piglet size and vitality at the same time [58]. Supplementation of pigs feed with probiotics can result in an improvement in meat quality attributes like color, marbling, tenderness, juiciness, and flavor [58]. In addition, pathogenic bacteria (E. coli, Salmonella, Clostridium difficile, Clostridium perfringens, Listeria), parasites (Isospora, Cryptosporidium), or viruses (Coronavirus, Rotavirus), which are triggering growth reduction and diarrhea, are more susceptible to intestinal colonization from birth to post-weaning piglets [127]. Many studies have assessed the effectiveness of probiotics during this episode and recommended the use of probiotics in this period [58]. Bacillus probiotic strains have been widely used in pigs. They can help to improve host gut health and immunity and reduce environmental pollutants like odor gas emissions from pig manure. For instance, inclusion of Bacillus subtilis $\mathrm{H} 4$ strain as feed additive resulted in a decrease in scouring in weaned pigs challenged with enterotoxigenic E. coli K88. Also, supplementation of basal diets for growing-finishing pigs with BioPlus 2B (B. licheniformis and B. subtilis) resulted in a decrease in morbidity and mortality, increase in fattening pig performance parameters and improve of carcass con- 
sistency [23]. In addition, this combination of B. subtilis and $B$. licheniformis spores decreased body weight of gestating sows, reduced prevalence of diarrhea and mortality in piglets, increased weaning litter weight and growth rate of young piglets [58]. Moreover, the use of B. cereus as probiotic conferred not just a lower incidence of diarrhea in pigs, but also a better FCR [58].

\section{In Fish}

In aquaculture, dietary supplementation of probiotics offers an environmentally friendly preventive prophylactic measure in terms of fish growth performance and health [129]. Probiotic strains that belong to the genus Bacillus are thought to be important tools for promoting sustainable aquaculture owing to their significant beneficial effects for aquaculture industry. They exert positive effects through multiple mechanisms like promotion of growth performance by production of enzymes increasing efficiency of feed utilization, suppression of disease invasion by stimulation of immunity, and improvement of aquatic ecosystems for growth and reproduction of fishes [8]. For instance, optimum supplementation of probiotic Bacillus species to Oreochromis mossambicus and Lates calcarifer can increase the specific growth rate and decrease the FCR. Bacillus can contribute to increasing the fecundity, survival rate, number of red and white blood cells in blood, stress, and disease resistance. Also, administration of Bacillus probiotics can stimulate the activity of intestinal enzymes contributing to efficient digestion in fish [129]. On the other hand, by secretion of enzymes or release of auto-inducer antagonists, certain probiotic bacteria including $B$. cereus strains permit degradation of pathogen signaling molecules (quorum quenching) [130].

In aquaculture, the administration of Bacillus probiotic strains can enhance the disease resistance against several bacterial pathogens. Obviously, following diet supplementation with Bacillus, an increased resistance against Streptococcus iniae [131], Aeromonas hydrophila [132], Acinetobacter sp. and Acinetobacter tandoii [28], and Aeromonas salmonicida, Streptococcus agalactiae, Lactococcus garvieae, and Vibrio parahemolyticus [133] has been recorded. The improvement in health status and disease resistance by dietary administration of $B$. subtilis probiotic strains has also been observed in different aquatic species including rainbow trout [134] and tilapia [135]. Administration of Bacillus strain TC22 (at $10^{9} \mathrm{CFU} \mathrm{g}^{-1}$ of feed) alone or in combination with prebiotic fructo-oligosaccharide at $0.5 \%$, resulted in increased phagocytosis, respiratory burst, and phenoloxidase activity of sea cucumber Apostichopus japonicas and disease resistance against Vibrio splendidus infection [136]. Bacillus sp. (PM4) and B. subtilis from a commercial product that demonstrated high inhibitory activity towards $V$. mimicus and $V$. cholera non-01, while
B. mycoides, isolated from marron inhibited just $V$. mimicus [137]. Recently, B. subtilis WS1A strain originating from a Bay of Bengal sponge demonstrated antagonistic activity on fish bacterial pathogens [138].

Probiotic bacilli have been reported to greatly improve the quality of water by preserving the equilibrium of several physicochemical parameters, regulating of the composition and abundance of microbial species by antagonism, decomposing various organic waste, and keeping the ecosystem safe for aquaculture [139]. It is evident that Bacillus has a huge potential to contribute to the sustainability of fish farming by improving water quality and preserving the total welding of cultivated fish such as growth improvement, feed usage, immune system responses, and defense against infectious diseases, especially infection by pathogenic bacteria [8]. The current state of Bacillus probiotics use in aquaculture needs intensive further research and vigilant application.

\section{Bacillus Spore Innovation Entailing Nanobiotechnology, Adsorption, and Surface Display of Proteins for Improving Feed Utilization Efficiency}

Bacillus subtilis has the ability to adapt to severe nutrients scarcity by entering in a complex differentiation process, resulting in the development of highly resistant spores. The spore consists of a central core compartment containing a clone of the chromosome and is enveloped by a dense layer known as the cortex, a transformed type of peptidoglycan. A multilayered protein coat covered the cortex. It is formed by an inner layer attached to the cortex in addition to an outer layer of a protein structure that protects the spore from toxic chemicals, lytic enzymes, and protozoan phagocytic predation [140]. The characteristics of coat layers of Bacillus spores have recently qualified them as emerging nanostructure that provides a fresh and fascinating surface to display several biomolecules [141]. Since B. subtilis has a clear safety record (GRAS) as an additive in human as well as animal preparations, display of functional molecules like enzymes on spore coat has great potential of application in the field of probiotics [142]. The display of feed enzymes on the Bacillus spore surface can guarantee effective implementation of enzymatic action in situ at a reasonable expense. Xylanase, hemicellulase, cellulase, protease, glycanase, or phytase are examples of feed enzymes that are candidates for display [140]. Bacillus strains are not only important as probiotics for animal farming, but may also be of use as a vehicle system for a number of molecules in so-called nanobiotechnology [23]. Recently, the extensive developments in molecular biology as well as cell biology have contributed to the identification of a wide range of large bacterial and viral antigens [143]. However, the translation of such antigens into efficient vaccines is con- 
ditioned by a delivery mechanism that is able to avoid loss of biological activity that sometimes impairs the potency of antigen [143]. Recently, Bacillus spp. spores have proven their ability to be used to design vaccines for the next generation [144]. The bacterial spore is a cell form that provides a potentially useful method for delivering antigens to mucosal surfaces [143]. Spore has unusual properties of resilience and can withstand high temperatures, dehydratation, and exposure to solvents and additional toxic chemicals [143]. These special features make the Bacillus spore an attractive vehicle for the delivery of heterologous proteins, enzymes, antigens, and other bioactive molecules to targeted niches, such as the GIT [145]. Besides, the spores of recombinant $B$. subtilis have been described as a possible bioremediation device for adsorption of ions like nickel [146]. The CotB spore surface protein was developed to express eighteen residues of histidine inside the spore coat [146]. When tested to determine their efficacy in adsorbing nickel ions, recombinant spores proved to be slightly more successful in metal-binding than wild type ones [146]. The simple purification process, high robustness, and remarkable efficacy of $B$. subtilis spores in nickel binding render the recombinant spore an innovative and effective instrument with promising potential for the bioremediation of polluted environments [146].

\section{Conclusion}

The aim of the present study was to determine the beneficial effects of Bacillus probiotics administration in monogastric animals. The use of Bacillus DFM in these animals is increasingly growing, as seen by the increase in research studies investigating the regulation of gut microbiome and immune activation in these hosts. The ability of Bacillus species to survive feed processing and provide the host gut with their benefits is an advantage over several other widely studied non-Bacillus-based DFM, in addition to their commercial availability for large-scale use. There is an evidence that through decreasing the excessive growth of bacteria in the small intestine via the development of antimicrobial peptides, Bacillus DFM decrease competition for nutrients, encourage the proliferation of beneficial bacteria and production of bioactive metabolites, and change the immune system response to the host's advantage. All these are examples of modes of action that culminate in promoting the animal growth. Although the beneficial effects of various Bacillus bacteria are not identical, the next mechanisms of action elucidation steps may comprise the identification of global metabolites developed to understand the relationship between supplemented probiotic and host bacteria in the presence of well performing Bacillus DFM.
Supplementary Information The online version contains supplementary material available at https://doi.org/10.1007/s12602-022-09909-5.

Acknowledgements We highly appreciate Dr. Mohammed Y. Refai, Dr. Zina Z. H. Amri, and Dr. Wafaa A. D. Alshehri from the Department of Biological Sciences at the College of Science-University of Jeddah for their generous support.

Author Contribution Conceptualization, Hichem Chouayekh. Writing original draft, Shifa A. Bahaddad and Meshal H. K.Almalki Writing review and editing, Othman A. Alghamdi, Sayed S. Sohrab, Muhammad Yasir, Esam I. Azhar, and Hichem Chouayekh

Funding This work was supported by the ICGEB project no. "CRP/ SAU20-01" and the Distinguished Scientific Researches project no. UJ-20-030-DR University of Jeddah.

\section{Declarations}

Conflict of Interest The authors declare no competing interests.

\section{References}

1. Thornton PK (2010) Livestock production: recent trends, future prospects. Philos Trans R Soc 365(1554):2853-2867. https://doi. org/10.1098/rstb.2010.0134

2. Henchion M, Hayes M, Mullen AM, Fenelon M, Tiwari B (2017) Future protein supply and demand: strategies and factors influencing a sustainable equilibrium. Foods 6(7):53. https://doi.org/ 10.3390/foods6070053

3. Gadde U, Kim W, Oh S, Lillehoj HS (2017) Alternatives to antibiotics for maximizing growth performance and feed efficiency in poultry: a review. Anim Health Res Rev 18(1):26-45

4. Imperial IC, Ibana JA (2016) Addressing the antibiotic resistance problem with probiotics: reducing the risk of its double-edged sword effect. Front Microbiol 7:1983. https://doi.org/10.3389/ fmicb.2016.01983

5. Ben Y, Fu C, Hu M, Liu L, Wong MH, Zheng C (2019) Human health risk assessment of antibiotic resistance associated with antibiotic residues in the environment: a review. Environ Res 169:483-493. https://doi.org/10.1016/j.envres.2018.11.040

6. Aarestrup FM (2015) The livestock reservoir for antimicrobial resistance: a personal view on changing patterns of risks, effects of interventions and the way forward. Philos Trans R Soc 370(1670):20140085. https://doi.org/10.1098/rstb.2014.0085

7. Laxminarayan R, Van Boeckel T, Teillant A (2015). The economic costs of withdrawing antimicrobial growth promoters from the livestock sector. https://doi.org/10.1787/18156797

8. Kuebutornye FK, Abarike ED, Lu Y (2019) A review on the application of Bacillus as probiotics in aquaculture. Fish Shellfish Immunol 87:820-828. https://doi.org/10.1016/j.fsi.2019.02. 010

9. Grant AQ, Gay CG, Lillehoj HS (2018) Bacillus spp. as direct-fed microbial antibiotic alternatives to enhance growth, immunity, and gut health in poultry. Avian Pathol 47(4):339-351. https:// doi.org/10.1080/03079457.2018.1464117

10. Pandey KR, Naik SR, Vakil BV (2015) Probiotics, prebiotics and synbiotics-a review. J Food Sci Technol 52(12):7577-7587

11. Long SS, Prober CG, Fischer M (2017) Principles and practice of pediatric infectious diseases E-Book. Elsevier Sci.

12. Soares MB, Almada CN, Almada CN, Martinez RC, Pereira EP, Balthazar CF, Cruz AG, Ranadheera CS, Sant'Ana AS (2019) 
Behavior of different Bacillus strains with claimed probiotic properties throughout processed cheese ("requeijão cremoso") manufacturing and storage. Int J Food Microbiol 307:108288. https://doi.org/10.1016/j.ijfoodmicro.2019.108288

13. Kim J-A, Bayo J, Cha J, Choi YJ, Jung MY, Kim D-H, Kim Y (2019) Investigating the probiotic characteristics of four microbial strains with potential application in feed industry. PLoS ONE 14(6):e0218922. https://doi.org/10.1371/journal.pone. 0218922

14. Liu X-F, Li Y, Li J-R, Cai L-Y, Li X-X, Chen J-R, Lyu S-X (2015) Isolation and characterisation of Bacillus spp. antagonistic to Vibrioparahaemolyticus for use as probiotics in aquaculture. World J Microbiol Biotechnol 31(5):795-803. https://doi. org/10.1007/s11274-015-1833-2

15. Dutta D, Ghosh K (2015) Screening of extracellular enzymeproducing and pathogen inhibitory gut bacteria as putative probiotics in mrigal, Cirrhinus mrigala (Hamilton. Int J Fish Aquat 2(4):310-318

16. Latorre Cardenas JD (2016) Evaluation and selection of a Bacillus based direct-fed microbial candidate for in situ enzyme production to improve gut health integrity, bone quality and growth performance in Poultry. https://doi.org/10.3389/fvets.2016.00095

17. Wan MLY, Forsythe SJ, El-Nezami H (2019) Probiotics interaction with foodborne pathogens: a potential alternative to antibiotics and future challenges. Crit Rev Food Sci Nutr 59(20):3320-3333. https://doi.org/10.1080/10408398.2018. 1490885

18. Latorre J, Hernandez-Velasco X, Vicente J, Wolfenden R, Hargis B, Tellez G (2017) Effects of the inclusion of a Bacillus directfed microbial on performance parameters, bone quality, recovered gut microflora, and intestinal morphology in broilers consuming a grower diet containing corn distillers dried grains with solubles. Poult Sci 96(8):2728-2735. https://doi.org/10.3382/ps/ pex082

19. Kruger C (2018) Extended shelf life milk processing: effect of cleaning in place (CIP) on the germination and attachment of Bacillus cereus spores.

20. Vieco-Saiz N, Belguesmia Y, Raspoet R, Auclair E, Gancel F, Kempf I, Drider D (2019) Benefits and inputs from lactic acid bacteria and their bacteriocins as alternatives to antibiotic growth promoters during food-animal production. Front Microbiol 10:57. https://doi.org/10.3389/fmicb.2019.00057

21. Guo X, Chen D-D, Peng K-S, Cui Z-W, Zhang X-J, Li S, Zhang Y-A (2016) Identification and characterization of Bacillus subtilis from grass carp (Ctenopharynodon idellus) for use as probiotic additives in aquatic feed. Fish Shellfish Immunol 52:74-84. https://doi.org/10.1016/j.fsi.2016.03.017

22. Smolentseva O (2017) The Effects of commensal B. subtilis biofilm on C. elegans physiology. https://doi.org/10.1038/ s41598-017-07222-8

23. Mingmongkolchai S, Panbangred W (2018) Bacillus probiotics: an alternative to antibiotics for livestock production. J Appl Microbiol 124(6):1334-1346. https://doi.org/10.1111/jam.13690

24. Hmani H, Daoud L, Jlidi M, Jalleli K, Ali MB, Brahim AH, Bargui M, Dammak A, Ali MB (2017) A Bacillus subtilis strain as probiotic in poultry: selection based on in vitro functional properties and enzymatic potentialities. J Ind Microbiol Biotechnol 44(8):11571166. https://doi.org/10.1007/s10295-017-1944-x

25. van der Peet-Schwering C, Verheijen R, Jørgensen L, Raff L (2020) Effects of a mixture of Bacillus amyloliquefaciens and Bacillus subtilis on the performance of growing-finishing pigs. Anim Feed Sci Technol 261:114409. https://doi.org/10.1016/j. anifeedsci.2020.114409

26. Zokaeifar H, Balcázar JL, Kamarudin MS, Sijam K, Arshad A, Saad CR (2012) Selection and identification of non-pathogenic bacteria isolated from fermented pickles with antagonistic prop- erties against two shrimp pathogens. J Antibiot 65(6):289-294. https://doi.org/10.1038/ja.2012.17

27. Hu Y, Dun Y, Li S, Zhao S, Peng N, Liang Y (2014) Effects of Bacillus subtilis $\mathrm{KN}-42$ on growth performance, diarrhea and faecal bacterial flora of weaned piglets. Asian Australas J Anim Sci 27(8):1131. https://doi.org/10.5713/ajas.2013.13737

28. Kavitha M, Raja M, Perumal P (2018) Evaluation of probiotic potential of Bacillus spp. isolated from the digestive tract of freshwater fish Labeo calbasu (Hamilton, 1822). Aquaculture Reports 11:59-69. https://doi.org/10.1016/j.aqrep.2018.07.001

29. Hayashi RM, Lourenço MC, Kraieski AL, Araujo RB, GonzalezEsquerra R, Leonardecz E, da Cunha AF, Carazzolle MF, Monzani PS, Santin E (2018) Effect of feeding Bacillus subtilis spores to broilers challenged with Salmonella enterica serovar Heidelberg Brazilian strain UFPR1 on performance, immune response, and gut health. Front Vet Sci 5:13. https://doi.org/10.3389/fvets.2018. 00013

30. Klopper KB (2017) Isolation and characterization of novel Lactobacillus spp. with promising gastro-intestinal survival and adhesion properties.

31. Ruíz García L, Gueimonde Fernández M, Ruas-Madiedo P, Margolles Barros A, Sánchez García B (2016) Improving probiotics for functional foods.

32. Elshaghabee FM, Rokana N, Gulhane RD, Sharma C, Panwar $\mathrm{H}$ (2017) Bacillus as potential probiotics: status, concerns, and future perspectives. Front Microbiol 8:1490. https://doi.org/10. 3389/fmicb.2017.01490

33. Stojanov S, Berlec A, Strukelj B (2020) The influence of probiotics on the Firmicutes/Bacteroidetes ratio in the treatment of obesity and inflammatory bowel disease. Microorganisms 8(11):1715. https://doi.org/10.3390/microorganisms8111715

34. Wang Y, Wu Y, Wang Y, Fu A, Gong L, Li W, Li Y (2017) Bacillus amyloliquefaciens SC06 alleviates the oxidative stress of IPEC-1 via modulating Nrf2/Keap1 signaling pathway and decreasing ROS production. Appl Microbiol Biotechnol 101(7):3015-3026. https://doi.org/10.1007/s00253-016-8032-4

35. Pan D, Yu Z (2014) Intestinal microbiome of poultry and its interaction with host and diet. Gut Microbes 5(1):108-119. https://doi.org/10.4161/gmic.26945

36. Soni A, Oey I, Silcock P, Bremer P (2016) Bacillus spores in the food industry: a review on resistance and response to novel inactivation technologies. Compr Rev Food Sci 15(6):11391148. https://doi.org/10.1111/1541-4337.12231

37. Cartman ST, La Ragione RM, Woodward MJ (2008) Bacillus subtilis spores germinate in the chicken gastrointestinal tract. Appl Environ Microbiol 74(16):5254-5258. https://doi.org/10. 1128/AEM.00580-08

38. Llewellyn A, Foey A (2017) Probiotic modulation of innate cell pathogen sensing and signaling events. Nutrients 9(10):1156. https://doi.org/10.3390/nu9101156

39. Pickard JM, Zeng MY, Caruso R, Núñez G (2017) Gut microbiota: role in pathogen colonization, immune responses, and inflammatory disease. Immunol Rev 279(1):70-89. https://doi. org/10.1111/imr.12567

40. Batista MT, Souza RD, Paccez JD, Luiz WB, Ferreira EL, Cavalcante RC, Ferreira RC, Ferreira LC (2014) Gut adhesive Bacillus subtilis spores as a platform for mucosal delivery of antigens. Infect Immun 82(4):1414-1423. https://doi.org/10. 1128/IAI.01255-13

41. Da Silva C, Wagner C, Bonnardel J, Gorvel J-P, Lelouard H (2017) The Peyer's patch mononuclear phagocyte system at steady state and during infection. Front Immunol 8:1254. https://doi.org/10.3389/fimmu.2017.01254

42. Lefevre M, Racedo SM, Ripert G, Housez B, Cazaubiel M, Maudet C, Jüsten P, Marteau P, Urdaci MC (2015) Probiotic strain Bacillus subtilis CU1 stimulates immune system 
of elderly during common infectious disease period: a randomized, double-blind placebo-controlled study. Immun Ageing 12(1):1-11. https://doi.org/10.1186/s12979-015-0051-y

43. Lobionda S, Sittipo P, Kwon HY, Lee YK (2019) The role of gut microbiota in intestinal inflammation with respect to diet and extrinsic stressors. Microorganisms 7(8):271. https://doi.org/10. 3390/microorganisms 7080271

44. Celi P, Cowieson A, Fru-Nji F, Steinert R, Kluenter A-M, Verlhac V (2017) Gastrointestinal functionality in animal nutrition and health: new opportunities for sustainable animal production. Anim Feed Sci Technol 234:88-100. https://doi.org/10.1016/j.anifeedsci.2017.09. 012

45. Kim JJ, Khan WI (2013) Goblet cells and mucins: role in innate defense in enteric infections. Pathogens 2(1):55-70. https://doi. org/10.3390/pathogens2010055

46. Bhullar K (2016) Mucus-bacteria interactions in the gut: investigating the role of the mucin Muc2 and its glycosylation in host defense during enteric bacterial infections.Thesis,University of British Columbia

47. Su L, Wang J, Huang J, Zhao Y, Jiang H, Li H (2019) Suppresses of astragalus polysaccharide on E. coli-induced injured intestinal microvascular through TLR4-NF- $\mathrm{KB}$ signal pathways in Chickens. Braz J Poult Sci 21(3). https://doi.org/10.1590/ 1806-9061-2018-0945

48. Gadde UD, Oh S, Lee Y, Davis E, Zimmerman N, Rehberger T, Lillehoj HS (2017) Dietary Bacillus subtilis-based direct-fed microbials alleviate LPS-induced intestinal immunological stress and improve intestinal barrier gene expression in commercial broiler chickens. Res Vet Sci 114:236-243. https://doi.org/10. 1016/j.rvsc.2017.05.004

49. Choi A-R, Patra JK, Kim WJ, Kang S-S (2018) Antagonistic activities and probiotic potential of lactic acid bacteria derived from a plant-based fermented food. Front Microbiol 9:1963. https://doi.org/10.3389/fmicb.2018.01963

50. Monteagudo-Mera A, Rastall RA, Gibson GR, Charalampopoulos D, Chatzifragkou A (2019) Adhesion mechanisms mediated by probiotics and prebiotics and their potential impact on human health. Appl Microbiol Biotechnol 103(16):6463-6472. https:// doi.org/10.1007/s00253-019-09978-7

51. Pahumunto N, Dahlen G, Teanpaisan R (2021) Evaluation of potential probiotic properties of Lactobacillus and Bacillus strains derived from various sources for their potential use in Swine feeding. Probiotics Antimicrob Proteins 1-12. https://doi. org/10.1007/s12602-021-09861-w.

52. Perez KJ, Viana JdS, Lopes FC, Pereira JQ, Dos Santos DM, Oliveira JS, Velho RV, Crispim SM, Nicoli JR, Brandelli A (2017) Bacillus spp. isolated from puba as a source of biosurfactants and antimicrobial lipopeptides. Front Microbiol 8:61. https://doi.org/10.3389/fmicb.2017.00061

53. Caulier S, Nannan C, Gillis A, Licciardi F, Bragard C, Mahillon J (2019) Overview of the antimicrobial compounds produced by members of the Bacillus subtilis group. Front Microbiol 10:302. https://doi.org/10.3389/fmicb.2019.00302

54. Cesa-Luna C, Baez A, Quintero-Hernández V, CRUZENRÍQUEZ JDL, Castañeda-Antonio MD, Muñoz-Rojas J (2020) The importance of antimicrobial compounds produced by beneficial bacteria on the biocontrol of phytopathogens. Acta biol Colomb 25(1):140-154. https://doi.org/10.15446/abc.v25n1. 76867

55. Garrison A (2019) Characterization and evaluation of the probiotic properties of the sporeforming bacteria, Bacillus coagulans unique IS-2.Thesis,University of Nebraska - Lincoln

56. Latorre JD, Hernandez-Velasco X, Wolfenden RE, Vicente JL, Wolfenden AD, Menconi A, Bielke LR, Hargis BM, Tellez G (2016) Evaluation and selection of Bacillus species based on enzyme production, antimicrobial activity, and biofilm synthesis as direct-fed microbial candidates for poultry. Front Vet Sci 3:95. https://doi.org/10.3389/fvets.2016.00095

57. Reineke K (2012). Mechanisms of Bacillus spore germination and inactivation during high pressure processing. https://doi.org/ 10.1016/j.tim.2013.03.001

58. Ahasan A, Agazzi A, Invernizzi G, Bontempo V, Savoini G (2015) The beneficial role of probiotics in monogastric animal nutrition and health. Dairy, Veterinary \& Animal Research. https://doi.org/10.15406/jdvar.2015.02.00041

59. Gharbi Y, Fhoula I, Ruas-Madiedo P, Afef N, Boudabous A, Gueimonde M, Ouzari H-I (2019) In-vitro characterization of potentially probiotic Lactobacillus strains isolated from human microbiota: interaction with pathogenic bacteria and the enteric cell line HT29. Annals of Microbiology 69(1):61-72. https://doi. org/10.1007/s13213-018-1396-1

60. Bernardeau M, Lehtinen M, Forssten S, Nurminen P (2017) Importance of the gastrointestinal life cycle of Bacillus for probiotic functionality. J Food Sci Technol 54(8):2570-2584. https://doi.org/10.1007/s13197-017-2688-3

61. Choi N-Y, Bae Y-M, Lee S-Y (2015) Cell surface properties and biofilm formation of pathogenic bacteria. Food Sci Biotechnol 24(6):2257-2264. https://doi.org/10.1007/s10068-015-0301-y

62. Latorre JD, Hernandez-Velasco X, Kuttappan VA, Wolfenden RE, Vicente JL, Wolfenden AD, Bielke LR, Prado-Rebolledo OF, Morales E, Hargis BM (2015) Selection of Bacillus spp. for cellulase and xylanase production as direct-fed microbials to reduce digesta viscosity and Clostridium perfringens proliferation using an in vitro digestive model in different poultry diets. Front Vet Sci 2:25. https://doi.org/10.3389/fvets.2015.00025

63. Kuebutornye FK, Abarike ED, Lu Y, Hlordzi V, Sakyi ME, Afriyie G, Wang Z, Li Y, Xie CX (2020) Mechanisms and the role of probiotic Bacillus in mitigating fish pathogens in aquaculture. Fish Physiol Biochem 1-23. https://doi.org/10. 1007/s10695-019-00754-y

64. Ayres V, Broomhead J, Li X, Raab R, Moritz J (2019) Viscosity and growth response of broilers fed high fiber diets supplemented with a corn-produced recombinant carbohydrase. J Appl Poultry Res 28(4):826-836. https://doi.org/10.3382/japr/ pfz039

65. Yaghobfar A, Kalantar M (2017) Effect of non-starch polysaccharide (NSP) of wheat and barley supplemented with exogenous enzyme blend on growth performance, gut microbial, pancreatic enzyme activities, expression of glucose transporter (sglt1) and mucin producer (muc2) genes of broiler chickens. Braz J Poult Sci 19(4):629-638. https://doi.org/10.1590/ 1806-9061-2016-0441

66. Thakur N, Rokana N, Panwar H (2016) Probiotics, selection criteria, safety and role in health and disease. J Innov Biol 3(1):259-270

67. Bisen P, Debnath M, Prasad G (2012) Identification and classification of microbes. Microbes

68. Das S, Dash HR, Mangwani N, Chakraborty J, Kumari S (2014) Understanding molecular identification and polyphasic taxonomic approaches for genetic relatedness and phylogenetic relationships of microorganisms. J Microbiol Methods 103:80-100. https://doi.org/10.1016/j.mimet.2014.05.013

69. Fitzpatrick MA, Ozer EA, Hauser AR (2016) Utility of wholegenome sequencing in characterizing Acinetobacter epidemiology and analyzing hospital outbreaks. J Clin Microbiol 54(3):593-612. https://doi.org/10.1128/JCM.01818-15

70. Fontana L, Bermudez-Brito M, Plaza-Diaz J, Munoz-Quezada S, Gil A (2014) Sources, isolation, characterisation and evaluation of probiotics-CORRIGENDUM. Br J Nutr 111(4):760-760. https://doi.org/10.1017/S0007114513003127

71. Li P, Tian W, Jiang Z, Liang Z, Wu X, Du B (2018) Genomic characterization and probiotic potency of Bacillus sp. DU-106, a 
highly effective producer of L-lactic acid isolated from fermented yogurt. Fronti Microbiol 9:2216. https://doi.org/10.3389/fmicb. 2018.02216

72. Tewari A, Abdullah S (2015) Bacillus cereus food poisoning: international and Indian perspective. J Food Sci Technol 52(5):2500-2511. https://doi.org/10.1007/s13197-014-1344-4

73. Liu MM, Coleman S, Wilkinson L, Smith ML, Hoang T, Niyah N, Mukherjee M, Huynh S, Parker CT, Kovac J (2020) Unique inducible filamentous motility identified in pathogenic Bacillus cereus group species. ISME J 1-14."Thttps://doi.org/10.1038/ s41396-020-0728-X

74. Visiello R, Colombo S, Carretto E (2016) Bacillus cereus hemolysins and other virulence factors. B Cereus 35-44. https://doi. org/10.1016/B978-0-12-801474-5.00003-7

75. Gopal N, Hill C, Ross PR, Beresford TP, Fenelon MA, Cotter PD (2015) The prevalence and control of Bacillus and related sporeforming bacteria in the dairy industry. Front Microbiol 6:1418. https://doi.org/10.3389/fmicb.2015.01418

76. Authority EFS (2014) Outcome of the public consultation on the draft Guidance on the assessment of the toxigenic potential of Bacillus species used in animal nutrition. EFSA support publ 11(5):587E. https://doi.org/10.2903/j.efsa.2014.3665

77. Babakhani S, Oloomi M (2018) Transposons: the agents of antibiotic resistance in bacteria. J Basic Microbiol 58(11):905-917. https://doi.org/10.1002/jobm.201800204

78. Lerner A, Matthias T, Aminov R (2017) Potential effects of horizontal gene exchange in the human gut. Front Immunol 8:1630. https://doi.org/10.3389/fimmu.2017.01630

79. Varankovich NV, Nickerson MT, Korber DR (2015) Probioticbased strategies for therapeutic and prophylactic use against multiple gastrointestinal diseases. Front Microbiol 6:685. https://doi. org/10.3389/fmicb.2015.00685

80. Dai M, Lu J, Wang Y, Liu Z, Yuan Z (2012) In vitro development and transfer of resistance to chlortetracycline in Bacillus subtilis. J Microbiol 50(5):807-812. https://doi.org/10.1007/s12275-012-1454-5

81. Aslam B, Wang W, Arshad MI, Khurshid M, Muzammil S, Rasool MH, Nisar MA, Alvi RF, Aslam MA, Qamar MU (2018) Antibiotic resistance: a rundown of a global crisis. Infect Drug Resist 11:1645. https://doi.org/10.2147/IDR.S173867

82. Additives EPo, Feed PoSuiA, (2012) Guidance on the assessment of bacterial susceptibility to antimicrobials of human and veterinary importance. EFSA J 10(6):2740. https://doi.org/10. 2903/j.efsa.2012.2740

83. Vinderola G, Gueimonde M, Gomez-Gallego C, Delfederico L, Salminen S (2017) Correlation between in vitro and in vivo assays in selection of probiotics from traditional species of bacteria. Trends Food Sci Technol 68:83-90. https://doi.org/10.1016/j. tifs.2017.08.005

84. Gorsuch J, LeSaint D, VanderKelen J, Buckman D, Kitts CL (2019) A comparison of methods for enumerating bacteria in direct fed microbials for animal feed. J Microbiol Methods 160:124-129. https://doi.org/10.1016/j.mimet.2019.04.003

85. Davis C (2014) Enumeration of probiotic strains: review of culture-dependent and alternative techniques to quantify viable bacteria. J Microbiol Methods 103:9-17. https://doi.org/10.1016/j. mimet.2014.04.012

86. Marson BM, Concentino V, Junkert AM, Fachi MM, Vilhena RO, Pontarolo R (2020) Validation of analytical methods in a pharmaceutical quality system: an overview focused on hplc methods. Química Nova 43(8):1190-1203. https://doi.org/10. 21577/0100-4042.20170589

87. Chauhan A, Singh R (2019) Probiotics in aquaculture: a promising emerging alternative approach. Symbiosis 77(2):99-113. https://doi.org/10.1007/s13199-018-0580-1

88. Nishiyama T, Ashida N, Nakagawa K, Iwatani S, Yamamoto N (2020) Dietary Bacillus subtilis C-3102 Supplementation
Enhances the Exclusion of Salmonella enterica from Chickens. J Poul Sci 0200036. https://doi.org/10.2141/jpsa.0200036.

89. Farhat-Khemakhem A, Blibech M, Boukhris I, Makni M, Chouayekh H (2018) Assessment of the potential of the multienzyme producer Bacillus amyloliquefaciens US573 as alternative feed additive. J Sci Food Agric 98(3):1208-1215. https://doi. org $/ 10.1002 /$ jsfa. 8574

90. Gu S-B, Zhao L-N, Wu Y, Li S-C, Sun J-R, Huang J-F, Li D-D (2015) Potential probiotic attributes of a new strain of Bacillus coagulans CGMCC 9951 isolated from healthy piglet feces. World J Microbiol Biotechnol 31(6):851-863. https://doi.org/10. 1007/s11274-015-1838-x

91. Khan MIR, Kamilya D, Choudhury TG, Tripathy PS, Rathore G (2021) Deciphering the Probiotic Potential of Bacillus amyloliquefaciens COFCAU_P1 Isolated from the Intestine of Labeo rohita Through In Vitro and Genetic Assessment. Probiotics Antimicrob Proteins 1-13. https://doi.org/10.1007/ s12602-021-09788-2

92. Volzing K, Borrero J, Sadowsky MJ, Kaznessis YN (2013) Antimicrobial peptides targeting Gram-negative pathogens, produced and delivered by lactic acid bacteria. ACS Synth Biol 2(11):643650. https://doi.org/10.1021/sb4000367

93. Chau KM, Van TTH, Quyen DV, Le HD, Phan THT, Ngo NDT, Vo TDT, Dinh TT, Le HT, Khanh HHN (2021) Molecular identification and characterization of probiotic Bacillus species with the ability to control Vibrio spp. in wild fish intestines and sponges from the Vietnam Sea. Microorganisms 9(9):1927. https://doi.org/10.3390/microorganisms 9091927

94. Dobson A, Cotter PD, Ross RP, Hill C (2012) Bacteriocin production: a probiotic trait? Appl Environ Microbiol 78(1):1-6. https://doi.org/10.1128/AEM.05576-11

95. Perumal V, Yao Z, Kim JA, Kim H-J, Kim JH (2019) Purification and characterization of a bacteriocin, BacBS2, produced by Bacillus velezensis BS2 isolated from Meongge Jeotgal. https:// doi.org/10.4014/jmb.1903.03065.

96. An J, Zhu W, Liu Y, Zhang X, Sun L, Hong P, Wang Y, Xu C, Xu D, Liu H (2015) Purification and characterization of a novel bacteriocin CAMT2 produced by Bacillus amyloliquefaciens isolated from marine fish Epinephelus areolatus. Food Control 51:278-282. https://doi.org/10.1016/j.foodcont.2014.11.038

97. Bajagai YS, Klieve AV, Dart PJ, Bryden WL (2016) Probiotics in animal nutrition: production, impact and regulation. Food and Agriculture Organization of the United Nations

98. Guo M, Li M, Zhang C, Zhang X, Wu Y (2020) Dietary Administration of the Bacillus subtilis enhances immune responses and disease resistance in chickens. Front Microbiol 11:1768. https:// doi.org/10.3389/fmicb.2020.01768

99. Lee K-W, Lillehoj HS, Jang SI, Lee S-H (2014) Effects of salinomycin and Bacillus subtilis on growth performance and immune responses in broiler chickens. Res Vet Sci 97(2):304-308. https:// doi.org/10.1016/j.rvsc.2014.07.021

100. Rhayat L, Maresca M, Nicoletti C, Perrier J, Brinch KS, Christian S, Devillard E, Eckhardt E (2019) Effect of Bacillus subtilis strains on intestinal barrier function and inflammatory response. Front Immunol 10:564. https://doi.org/10.3389/fimmu.2019.00564

101. Liao J, Cai Y, Wang X, Shang C, Zhang Q, Shi H, Wang S, Zhang D, Zhou Y (2021) Effects of a potential host gut-derived probiotic, Bacillus subtilis 6-3-1, on the growth, non-specific immune response and disease resistance of hybrid grouper (Epinephelus fuscoguttatus $\bigcirc \times$ Epinephelus lanceolatus ${ }^{\lambda}$ ). Probiotics and Antimicrobial Proteins:1-19. https://doi.org/10.1007/ s12602-021-09768-6

102. Sandvang D, Skjoet-Rasmussen L, Cantor MD, Mathis GF, Lumpkins BS, Blanch A (2021) Effects of feed supplementation with 3 different probiotic Bacillus strains and their combination on the performance of broiler chickens challenged with 
Clostridium perfringens. Poult Sci 100(4):100982. https://doi. org/10.1016/j.psj.2021.01.005

103. KILIÇ İ, İhsan B, BOZKURT Z, DOĞAN YN (2020) The Effect of dietary probiotic supplementation on egg weight in laying hens: A meta-analysis study. Kocatepe Veteriner Dergisi 13(2):1-1. https://doi.org/10.30607/kvj.695761

104. Hernandez-Patlan D, Solis-Cruz B, Pontin KP, HernandezVelasco X, Merino-Guzman R, Adhikari B, López-Arellano R, Kwon YM, Hargis BM, Arreguin-Nava MA (2019) Impact of a Bacillus direct-fed microbial on growth performance, intestinal barrier integrity, necrotic enteritis lesions, and ileal microbiota in broiler chickens using a laboratory challenge model. Front Vet Sci 6:108. https://doi.org/10.3389/fvets.2019.00108

105. Baker JT, Duarte ME, Holanda DM, Kim SW (2021) Friend or foe? Impacts of dietary xylans, xylooligosaccharides, and xylanases on intestinal health and growth performance of monogastric animals. Animals 11(3):609. https://doi.org/10.3390/ ani11030609

106. Yuan L, Wang M, Zhang X, Wang Z (2017) Effects of protease and non-starch polysaccharide enzyme on performance, digestive function, activity and gene expression of endogenous enzyme of broilers. PLoS One 12(3)

107. Laachari F, El Bergadi F, Bahafid W, Sayari A, Elabed S, Mohammed I, Ibnsouda SK (2014) Biochemical study of lipases from Bacillus subtilis. Moroccan J Biol 11:1-9

108. Murad H, Azzaz H (2010) Cellulase and dairy animal feeding. Biotechnology 9(3):238-256. https://doi.org/10.3923/biotech. 2010.238.256

109. Lei XG, Weaver JD, Mullaney E, Ullah AH, Azain MJ (2013) Phytase, a new life for an "old" enzyme. Annu Rev Anim Biosci 1(1):283-309. https://doi.org/10.1146/annurev-animal-031412-103717

110. Brandelli A, Sala L, Kalil SJ (2015) Microbial enzymes for bioconversion of poultry waste into added-value products. Food Res Int 73:3-12. https://doi.org/10.1016/j.foodres.2015.01.015

111. Scapini L, de Cristo A, Schmidt J, Buzim R, Nogueira L, Palma S, Fernandes J (2019) Effect of $\beta$-Mannanase supplementation in conventional diets on the performance, immune competence and intestinal quality of broilers challenged with Eimeria sp. J Appl Poultry Res 28(4):1048-1057. https://doi.org/10.3382/japr/pfz066

112. Hu J, Kim YH, Kim IH (2021) Effects of two Bacillus strains probiotic supplement on reproduction performance, nutrient digestibility, blood profile, fecal score, excreta odor contents and fecal microflora in lactation sows, and growth performance in sucking piglets. Livest Sci 244:104293. https://doi.org/10.1016/j.livsci. 2020.104293

113. Jeong J, Kim I (2014) Effect of Bacillus subtilis C-3102 spores as a probiotic feed supplement on growth performance, noxious gas emission, and intestinal microflora in broilers. Poult Sci 93(12):3097-3103. https://doi.org/10.3382/ps.2014-04086

114. Olson EG, Dittoe DK, Micciche AC, Ricke SC (2020) Identification of bacterial isolates from commercial poultry feed via 16S rDNA. J Environ Sci Health - B Pestic Food Contam Agric Wastes 1-9. https://doi.org/10.1080/03601234.2020.1868236

115. Jayaraman S, Thangavel G, Kurian H, Mani R, Mukkalil R, Chirakkal H (2013) Bacillus subtilis PB6 improves intestinal health of broiler chickens challenged with Clostridium perfringensinduced necrotic enteritis. Poult Sci J 92(2):370-374. https:// doi.org/10.3382/ps.2012-02528

116. Sen S, Ingale S, Kim Y, Kim J, Kim K, Lohakare J, Kim E, Kim H, Ryu M, Kwon I (2012) Effect of supplementation of Bacillus subtilis LS 1-2 to broiler diets on growth performance, nutrient retention, caecal microbiology and small intestinal morphology. Res Vet Sci 93(1):264-268. https://doi.org/10.1016/j.rvsc.2011. 05.021

117. Latorre J, Hernandez-Velasco X, Bielke L, Vicente J, Wolfenden R, Menconi A, Hargis B, Tellez G (2015) Evaluation of a Bacil- lus direct-fed microbial candidate on digesta viscosity, bacterial translocation, microbiota composition and bone mineralisation in broiler chickens fed on a rye-based diet. Br Poult Sci 56(6):723732. https://doi.org/10.3389/fvets.2015.00025

118. Kim H, Yan F, Hu J, Cheng H, Kim Y (2016) Effects of probiotics feeding on meat quality of chicken breast during postmortem storage. Poult Sci 95(6):1457-1464. https://doi.org/10.3382/ps/ pew055

119. Mikulski D, Jankowski J, Naczmanski J, Mikulska M, Demey V (2012) Effects of dietary probiotic (Pediococcus acidilactici) supplementation on performance, nutrient digestibility, egg traits, egg yolk cholesterol, and fatty acid profile in laying hens. Poult Sci 91(10):2691-2700. https://doi.org/10.3382/ps.2012-02370

120. Awad WA, Hess C, Hess M (2017) Enteric pathogens and their toxin-induced disruption of the intestinal barrier through alteration of tight junctions in chickens. Toxins 9(2):60. https://doi. org/10.3390/toxins 9020060

121. Vicuna $E$ (2015) Intestinal inflammation model inducing gut leakage by different methods in broiler chickens using FITC-d as a marker. Thesis,Eduardo Vicuna, University of Arkansas, Fayetteville

122. Adhikari B, Hernandez-Patlan D, Solis-Cruz B, Kwon YM, Arreguin M, Latorre JD, Hernandez-Velasco X, Hargis BM, Tellez-Isaias G (2019) Evaluation of the antimicrobial and anti-inflammatory properties of Bacillus-DFM (NorumTM) in broiler chickens infected with Salmonella Enteritidis. Front Vet Sci 6:282. https://doi.org/10.3389/fvets.2019.00282

123. Ighodaro O, Akinloye O (2018) First line defence antioxidantssuperoxide dismutase (SOD), catalase (CAT) and glutathione peroxidase (GPX): their fundamental role in the entire antioxidant defence grid. Alexandria J Med 54(4):287-293. https://doi. org/10.1016/j.ajme.2017.09.001

124. Merino-Guzmán R, Latorre JD, Delgado R, Hernandez-Velasco X, Wolfenden AD, Teague KD, Graham LE, Mahaffey BD, Baxter MFA, Hargis BM (2017) Comparison of total immunoglobulin a levels in different samples in Leghorn and broiler chickens. Asian Pac J Trop Biomed 7(2):116-120

125. Heo J, Opapeju F, Pluske J, Kim J, Hampson D, Nyachoti C (2013) Gastrointestinal health and function in weaned pigs: a review of feeding strategies to control post-weaning diarrhoea without using in-feed antimicrobial compounds. J Anim Physiol Anim Nutr 97(2):207-237. https://doi.org/10.1111/j.1439-0396. 2012.01284.x

126. Campbell JM, Crenshaw JD, Polo J (2013) The biological stress of early weaned piglets. J Anim Sci Biotechnol 4(1):1-4. https:// doi.org/10.1186/2049-1891-4-19

127. Guevarra RB, Lee JH, Lee SH, Seok M-J, Kim DW, Kang BN, Johnson TJ, Isaacson RE, Kim HB (2019) Piglet gut microbial shifts early in life: causes and effects. J Anim Sci Biotechnol 10(1):1-10. https://doi.org/10.1186/s40104-018-0308-3

128. Knecht D, Cholewińska P, Jankowska-Mąkosa A, Czyż K (2020) Development of swine's digestive tract microbiota and Its relation to production indices-a review. Animals 10(3):527. https:// doi.org/10.3390/ani10030527

129. Rahman A, Shefat SHT, Chowdhury MA (2021) Effects of probiotic Bacillus on growth performance, immune response and disease resistance in aquaculture.

130. Hu X, Wen G, Xu W, Xu Y, Su H, Yang K, Xu Y, Li Z, Cao Y (2019) Effects of the algicidal bacterium CZBC1 on microalgal and bacterial communities in shrimp culture. Aquac Environ Interact 11:279-290. https://doi.org/10.3354/aei00311

131. Jayaprakashvel M, Subramani R (2019) Implications of quorum sensing and quorum quenching in aquaculture health management. In: Implication of quorum sensing and biofilm formation in medicine, agriculture and food Industry,299-312

132. Cha J-H, Rahimnejad S, Yang S-Y, Kim K-W, Lee K-J (2013) Evaluations of Bacillus spp. as dietary additives on growth per- 
formance, innate immunity and disease resistance of olive flounder (Paralichthys olivaceus) against Streptococcus iniae and as water additives. Aquaculture 402:50-57

133. Ramesh D, Souissi S (2018) Effects of potential probiotic Bacillus subtilis KADR1 and its subcellular components on immune responses and disease resistance in Labeo rohita. Aquac Res 49(1):367-377. https://doi.org/10.1111/are.13467

134. Yi Y, Zhang Z, Zhao F, Liu H, Yu L, Zha J, Wang G (2018) Probiotic potential of Bacillus velezensis JW: antimicrobial activity against fish pathogenic bacteria and immune enhancement effects on Carassius auratus. Fish Shellfish Immunol 78:322-330. https://doi.org/10.1016/j.fsi.2018.04.055

135. Newaj-Fyzul A, Adesiyun AA, Mutani A, Ramsubhag A, Brunt J, Austin B (2007) Bacillus subtilis AB1 controls Aeromonas infection in rainbow trout (Oncorhynchus mykiss, Walbaum). J Appl Microbiol 103(5):1699-1706. https://doi.org/10.1111/j. 1365-2672.2007.03402.x

136. Lakshmi B, Viswanath B, Sai Gopal D (2013) Probiotics as antiviral agents in shrimp aquaculture. J Pathog. https://doi.org/10. $1155 / 2013 / 424123$

137. Zhao Y, Mai K, Xu W, Zhang W, Ai Q, Zhang Y, Wang X, Liufu Z (2011) Influence of dietary probiotic Bacillus TC22 and Prebiotic fructooligosaccharide on growth, immune responses and disease resistance against Vibrio splendidus infection in sea cucumber Apostichopus japonicus. J Ocean Univ China 10(3):293-300. https://doi.org/10.1007/s11802-011-1855-9

138. Islam MT, Rahman MM, Pandey P, Boehme MH, Haesaert G (2019) Bacilli and agrobiotechnology: phytostimulation and biocontrol.Springer,

139. Rahman M, Paul S, Akter T, Tay A, Foysal M, Islam M (2020) Whole-genome sequence of Bacillus subtilis WS1A, a promising fish probiotic strain isolated from marine sponge of the Bay of
Bengal. Microbiol Resour Announc 9:e00641-e720. https://doi. org/10.1128/MRA.00641-20

140. Amaraweera K, Wijeyaratne M, Jayamanne S (2013) Growth and survival of post-larvae of giant freshwater prawn (Macrobrachium rosenbergii) reared using feeds formulated with different sources of protein. Sri Lanka J Aquat Sci 18:17-26. https://doi. org/10.4038/sljas.v18i0.7036

141. Potot S, Serra CR, Henriques AO, Schyns G (2010) Display of recombinant proteins on Bacillus subtilis spores, using a coat-associated enzyme as the carrier. Appl Environ Microbiol 76(17):5926-5933. https://doi.org/10.1128/AEM.01103-10

142. Zhang X, Al-Dossary A, Hussain M, Setlow P, Li J (2020) Applications of Bacillus subtilis spores in biotechnology and advanced materials. Appl Environ Microbiol 86(17):e01096-e11020. https://doi.org/10.1128/AEM.01096-20

143. Isticato R, Ricca E (2016) Spore surface display. The Bacterial Spore: From Molecules to Systems: 349-366. https://doi.org/10. 1128/9781555819323.ch17

144. Wang H, Wang Y, Yang R (2017) Recent progress in Bacillus subtilis spore-surface display: concept, progress, and future. Appl Microbiol Biotechnol 101(3):933-949. https://doi.org/10. 1007/s00253-016-8080-9

145. Arora S, Kumar N, Yadav A, Raghu HV (2016) Spore: potential of invaluable bacterial wrap. Int J Life Sci Scienti Res 2(5). https://doi.org/10.21276/ijlssr.2016.2.5.1

146. Tehri N, Kumar N, Raghu H, Shukla R, Vashishth A (2018) Microbial spores: concepts and industrial applications. Microbial Bioprospecting for Sustainable Development: 279-289. https:// doi.org/10.1007/978-981-13-0053-0_15

Publisher's Note Springer Nature remains neutral with regard to jurisdictional claims in published maps and institutional affiliations. 